\title{
REPRESENTASI NILAI-NILAI RELIGIUSITAS DALAM DESAIN ORNAMEN GONG SENEN JEPARA
}

\author{
Abdulloh Eizzi Irsyada1, Handry Rohmad Dwi Happy ${ }^{2}$ \\ ${ }^{1,2}$ DKV, Fakultas Teknologi dan Desain, Institut Teknologi dan Bisnis Asia Malang \\ abdulloheizzi@asia.ac.id ${ }^{1}$, handryhappy@asia.ac.id ${ }^{2}$
}

\begin{abstract}
Abstrak
Gong Senen merupakan karya ukir Jepara lampau yang dirancang langsung oleh Citrokusumo, yang merupakan Adipati Jepara, sekitaran tahun 1720 silam. Citrokusumo seolah-olah menjadikan Gong Senen sebagai sarana atau media berkomunikasi dengan warganya. Setiap ornamen pada Gong Senen mengandung nilai-nilai pesan religiusitas yang secara umum meliputi hubungan manusia dengan Tuhannya, sesamanya serta lingkungannya. Namun, pada masa modern ini, tidak banyak masyarakat Jepara, khususnya desa Senenan yang mengetahui karya ukiran bersejarah ini, begitu juga dengan pesan atau nilai yang terkandung pada setiap elemen ukirnya. Oleh karenanya, penelitian ini diharapkan mampu melacak, menganalisa hingga merangkum apa saja nilai-nilai religiusitas yang terepresentasi dalam setiap elemen-elemen ukiran Gong Senen Jepara. Penelitian ini merupakan penelitian kualitatif dengan metode deskriptif. Selain menggunakan pendekatan estetis dan historis, penelitian ini juga menggunakan teori tanda semiotika sebagai pisau analisisnya, dengan mengindikasikan objek ornamen sebagai penanda dan makna dibalik ornamen tersebut sebagai petanda. Adapun nilainilai filosofi kehidupan Adiluhung Jawa di balik kemegahan ornamen ukir Gong Senen ini adalah pesan kepada warga Jepara, sebagai contoh dalam ornamen merak untuk menjaga lima perkara sebelum datangnya lima perkara, yakni menjaga masa muda sebelum tua, sehat sebelum sakit, kaya sebelum miskin, sempat sebelum sempit, serta hidup sebelum mati.
\end{abstract}

Kata Kunci: desain, Gong Senen, Jepara, religiusitas, representasi

\begin{abstract}
Gong Senen is an ancient Jepara carving designed directly by Citrokusumo, the Duke of Jepara, around 1720. Citrokusumo seems to make Gong Senen a tool or medium to communicate with its citizens. Each ornament carved on Gong Senen consists of the values of the religious messages which generally includes the human relationship with God, each other, and the environment. Yet, Not many people of Jepara, especially Senenan village, know about this historic carving as well as the message or value contained in each element of the carving. Therefore, this research is expected to trace, analyze and summarize the religious values represented in each element of Gong Senen Jepara carve. This research is qualitative research with descriptive methods. In addition, besides using aesthetic and historical approaches, this study also uses semiotic sign theory as a tool of analysis, by indicating the ornament object as a signifier and the meaning behind the ornament as a signified. The philosophical values of the "Adiluhung" (great) Javanese life behind the splendor of this Gong Senen carved ornament are a message to Jepara's residents, as an example in peacock ornament to protect five matters before the arrival of five matters those are keeping the youth before the old, the health before the sick, the rich before the poverty, the ability before the inability, and the life before the death.
\end{abstract}

Keywords: design, Gong Senen, Jepara, representation, religiosity 


\section{PENDAHULUAN}

Jepara merupakan salah satu kota kabupaten di Jawa Tengah yang terkenal dengan julukan kota ukir. Julukan tersebut tidak terlepas dari banyaknya aktifitas mengukir dari jaman era Ratu Sima dulu kala, bahkan masih bertahan hingga masa modern ini. Jejak karya yang dihasilkan seniman ukir Jepara zaman dahulu bisa ditemui di masjid Kalinyamat Jepara. Beberapa seni ukir relief berbahankan batu karang putih ini masih menempel pada beberapa sisi di dinding masjid Kalinyamat, (Afif: 2019).

Karya lainnya juga bisa ditemui di komunitas Rumah Kartini. Di tempat ini terdapat karya ukir yang sangat bersejarah bernama Gong Senen. Gong Senen merupakan perpaduan dari alat musik gong dan gayor (tiang penyangga gong). Diberikan nama demikian karena dibuat oleh sang kreator di desa Senenan Jepara, namun dari sumber lain menyatakan bahwa nama Senen diambil karena gong ini dibunyikan setiap hari Senen atau Senin.

Umumnya, gong terbuat dari lempeng tembaga atau kuningan yang ditempa hingga menyerupai bejana terbalik. la merupakan salah satu bagian dari alat musik tradisional Jawa yang disebut gamelan. Umumnya serangkaian alat musik gamelan ini dipakai untuk mengiringi nyanyian-nyanyian pada acara adat Jawa. Sedang pada gayor-nya, oleh senimannya diukirlah beberapa elemen visual atau motif ornamen ukir seperti, floral atau tumbuh-tumbuhan, hewan naga, merak, figur karakter seseorang, manusia dan lain sebagainya dengan susunan yang hampir simetris.

Citrokusumo, kreator yang sekaligus merupakan Adipati Jepara menjadikan Gong Senen Jepara sebagai media berkomunikasi dengan warganya. Gong Senen kreasi Citrokusumo, layaknya mencerminkan beberapa falsafah yang merepresentasikan nilainilai religiusitas. Nardi (2019) dalam wawancara mengungkapkan, falsafah hidup yang terkandung dalam setiap elemen/motif ukir Gong Senen tersebut secara umum meliputi hubungan manusia dengan Tuhannya, hubungan manusia dengan sesamanya serta hubungan manusia dengan lingkungannya.

Namun, dewasa ini, Afif (2019) mengungkapkan bahwa masih sedikit masyarakat Jepara, khususnya desa Senenan yang mengetahui adanya karya ukiran bersejarah serta nilainilai yang ingin disampaikan Citrokusumo pada setiap elemen desain ornamen ukirnya. Harapannya, penelitian ini mampu untuk melacak, menganalisis hingga merangkum nilai-nilai religiusitas yang terrepresentasi dalam setiap desain ornamen ukir Gong Senen Jepara ditinjau dalam disiplin ilmu Desain Komunikasi Visual. Penelitian ini mampu menjadi literatur bagi para peneliti di masa mendatang, serta mampu menyegarkan kembali ingatan masyarakat Jepara khususnya karya ukir bersejarah yang penuh nilai falsafah hidup bernama Gong Senen.

\section{METODE PENELITIAN}

Penelitian ini merupakan penelitian kualitatif dengan metode deskriptif. Kualitatif merupakan metode analisis yang berlandaskan pada filsafat post positivisme, digunakan untuk meneliti pada kondisi objek yang alamiah, di mana peneliti adalah sebagi instrumen kunci. Lincoln dan Guba mengemukakan bahwa dalam pendekatan kualitatif 
peneliti memanfaatkan diri sebagai instrumen, karena instrumen nonmanusia (angket, pedoman wawancara, pedoman observasi, dan lain sebagainya) sulit digunakan secara luwes untuk menangkap berbagai realitas dan interaksi yang terjadi. Peneliti harus mampu mengungkap gejala sosial di lapangan dengan mengerahkan segenap fungsi inderawinya, (Mulyadi, 2011: 135). Sedangkan metode deskriptif dimaksudkan untuk eksplorasi dan klarifikasi mengenai sesuatu fenomena atau kenyataan sosial, dengan jalan mendeskripsikan sejumlah permasalahan yang berkenaan dengan masalah dan unit yang diteliti. Selain itu juga untuk menarik kesimpulan yang lebih luas terkait suatu temuan penilitian. (Mulyadi, 2011: 132).

Penelitian ini juga menggunakan pendekatan estetis dan historis yang digunakan untuk memperoleh gambaran mengenai apa saja nilai-nilai religiusitas yang terrepresentasi pada desain ornamen ukir Gong Senen Jepara. Pendekatan estetis digunakan dalam menyangkut pembahasan tentang bentuk dan visual pada desain ornamen ukir Gong Senen Jepara. Sedangkan pendekatan historis digunakan untuk memperoleh data sejarah yang melingkupi asal usul objek penelitian. Selain itu, penelitian ini juga menggunakan teori tanda semiotika sebagai alat analisis, dengan mengindikasikan objek ornamennya sebagai penanda dan makna dibalik ornamen tersebut sebagai petanda.

Adapun prosedur pelaksanaan penelitian secara keseluruhan yaitu pertama, studi pendahuluan. Peneliti terlebih dahulu melakukan studi pendahuluan, yaitu memfokuskan permasalahan-permasalahan yang ditemukan peneliti baik melalui studi literatur, observasi maupun melalui wawancara mengenai ukiran pada Gong Senen Jepara. Melalui studi pendahuluan yang dilakukan, selanjutnya peneliti memfokuskan permasalahan pada representasi nilai-nilai religiusitas pada desain ornamen ukir Gong Senen Jepara. Kedua, menentukan metode penelitian. Pada tahapan ini, peneliti menentukan metode penelitian yang sesuai dengan permasalahan yang menjadi fokus dalam penelitian. Menentukan teknik pengumpulan data dan instrumen yang tepat digunakan berdasarkan teknik pengumpulan data yang sesuai serta menentukan teknik analisa datanya.

Ketiga, pengumpulan data. Teknik pengumpulan data yang akan digunakan peneliti adalah observasi pada lingkup wilayah Jepara dan sekitarnya, sedangkan wawancara terhadap beberapa pakar juga perlu dilakukan oleh peneliti untuk menggali informasi yang tepat terkait topik yang diteliti, serta studi literatur guna menunjang hasil dari kedua teknik sebelumnya. Observasi dan wawancara ini merupakan salah satu teknik pengumpulan data utama dalam pendekatan kualitatif yang berfungsi sebagai bahan dalam melakukan analisis data secara mendalam, (Mulyadi, 2011: 135).

Wawancara yang dilakukan dengan mengambil informan kunci dan pendukung yang benar-benar memahami dan mengetahui mengenai kajian yang akan dikaji oleh peneliti, di antaranya adalah sebagai berikut; Bapak Kiai Nardi (pemerhati sejarah serta Penasihat Umum Komunitas Rumah Kartini), Bapak Afif Isyarobbi, (pemerhati sejarah kebudayaan Jepara, Pimpinan Komunitas Rumah Kartini). Sedangkan buku-buku yang dijadikan bahan studi literatur di antaranya adalah; Seni Kerajinan Mebel Ukir Jepara yang ditulis 
oleh SP. Gustami, diterbitkan oleh Kanisius pada tahun 2000, kemudian buku Risalah dan Kumpulan Data Tentang Perkembangan Seni Ukir Jepara yang ditulis oleh Pemerintah Kabupaten Daerah Tingkat II Jepara, diterbitkan oleh Silas Press Jepara pada tahun 1979; dan lain sebagainya. Terakhir keempat, pengolahan data. Tahap pengolahan data meliputi tahapan reduksi data, penyajian data, analisis data, sehingga menghasilkan suatu hasil penelitian yang mampu untuk ditarik kesimpulannya.

\title{
3. HASIL DAN PEMBAHASAN
}

\subsection{Sekilas tentang Gong Senen}

Afif (2019) dalam wawancara menjelaskan bahwa Jepara pada masa kepemimpinan Citrokusumo merupakan Jepara yang tengah membangun kembali kehidupan kotanya pasca dipindahkannya pelabuhan laut ke Semarang. Pemindahan pelabuhan laut ini menjadikan Jepara bukan sebagai kota yang ramai orang berlalu lalang, berbeda ketika pelabuhan utama masih berada di Jepara. Pemindahan ini juga menjadikan Jepara sebagai sebuah kota yang terlupakan. Sebagaimana kejadian ini juga diceritakan kembali oleh Kartini (1903) dalam artikelnya yang berjudul Sudut yang Terlupakan dalam bahasa Belanda, di majalah Eigen Haard ;

\begin{abstract}
"Engkau sangat manis, sangat memesona dengan udaramu yang damai; jalan-jalanmu yang indah dan teduh yang mengundang orang menapakinya, dengan sudut-sudut intim yang menyambut kawan berkumpul bercanda-tawa; alun-alun indahmu yang selalu terbentang dalam jubah hijau velvet dihiasi titik-titik bunga, yang berkembang dalam taman yang anggun, dikelilingi pohon beringin yang meneduhi rumah-rumah di belakangnya [...] ; laut surgawimu yang membuat kita lupa akan kekhawatiran duniawi kita, mengayun-ayun kita di atas buih ombaknya dan melingkupi kita dengan nafasnya yang segar, sehat dan membangkitkan semangat; pantai indahmu tempat orang bisa menikmati tontonan alami nan indah, lukisan penuh warna dan cahaya akan mentari yang meninggalkan langit dan bentangan air beriak, yang riaknya - sekarang hanya percikan kecil tapi lain kali mengalir serampangan - pecah di pasir putih."
\end{abstract}

Sampai akhirnya Citrokusumo dibantu oleh sahabat-sahabatnya seperti Tunggulwulung dan Sentono berdiskusi untuk mencari cara bagaimana membangkitkan kebersamaan para rakyat Jepara yang sedang memudar itu. Hingga akhirnya tercetuslah usulan untuk membuat Gong Senen sebagai media atau sarana pemersatu rakyat Jepara yang dipimpin Citrokusumo saat itu.

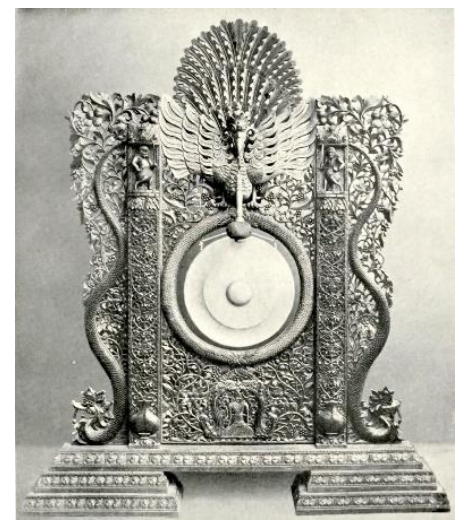

Gambar 1. Potret Gong Senen [Sumber: Koleksi Komunitas Rumah Kartini] 
Gong dengan berbagai macam filosofi yang luhur itu setelah jadi kemudian ditempatkan di pendopo kabupaten, dan dibunyikan bersamaan dengan adanya acara rutinan masyarakat Senenan yang selalu memainkan alat musik gamelan pada setiap hari Senin. Diciptakannya Gong Senen sebagai media pemersatu masyarakat Jepara ini merupakan salah satu solusi atas kebutuhan aktualisasi-diri (self actualization) pemerintahan Jepara kala itu yang dipimpin oleh Citrokusumo.

\subsection{Penanda dan Petanda pada Desain Ornamen Gong Senen}

Karya seni sebagai suatu substansi bentuk estetik dapat dikaitkan dengan fenomenafenomena yang ada. Salah satunya adalah keterkaitan antara karya seni yang ada dengan fenomena yang terjadi, berdasarkan pada suatu tanda dengan berorientasi pada upaya yang mempunyai tujuan untuk memperkaya ilmu pengetahuan manusia, dengan menghadirkan tanda penting yang tertuang dalam setiap kehadiran suatu karya seni. Keterkaitan karya seni dan fenomena ini dapat diyakini karena setiap penciptaan karya seni merupakan pencerminan visi zamannya seperti apa yang disebut oleh Copplestone (1983-30) sebagai "period vision", atau sesuatu yang menyiratkan semangat jaman. Sudah tentu, bahwa setiap karya seni tersebut diciptakan dalam keterkaitannya sebagai pemenuh kebutuhan dan atau tuntutan zamannya. Ditunjang oleh kondisi kemajuan peradaban yang ada.

Pembacaan tanda pada karya seni senantiasa menggunakan penalaran manusia akan sebuah tanda yang selalu dikaitkan dengan banyaknya pengalaman baik dalam pikirannya maupun dalam upayanya bersosialisasi dengan lingkungan. Hal ini senada dengan Pierce dalam Berger (2000: 11), penalaran manusia senantisa dilakukan lewat tanda. Artinya, manusia hanya dapat bernalar lewat tanda. Dalam pikirannya, logika sama dengan semiotika dan semiotika dapat diterapkan pada segala macam tanda. Pembacaan sebuah tanda merupakan bagian dari ilmu semiotika, menurut Pierce dalam Eco (1979: 15), tanda ialah suatu yang dapat mewakili sesuatu yang lain dalam batasbatas tertentu.

Saussure dalam Piliang (2004: 191) melukiskan hubungan antara penanda (signifier) dan petanda (signified) seperti selembar kertas, yang tidak mungkin untuk memisahkan antara satu sisinya dengan sisinya yang lain. Bidang penanda (signifier) untuk menjelaskan 'bentuk' atau 'ekspresi' sedangkan bidang petanda (signified), untuk menjelaskan 'konsep' atau 'makna'. Begitulah kesatuan antara penanda dan konsep di baliknya. Seikat bunga yang diberikan pada seseorang (penanda) tidak bisa dipisahkan dari konsep 'cinta' atau 'kasih sayang' di baliknya (petanda). Bunga yang tidak ada konsep dibaliknya bukanlah merupakan sebuah tanda.

Dalam sebuah karya seni, pemaknaan tanda akan mengalami perbedaan jika menilik pada di mana karya tersebut berada. Keanekaragaman budaya tiap daerah menjadikan tanda seni yang tergambar menjadi berbeda pemaknaanya tergantung dari kualitas pengalaman yang ada. Pemaknaan karya seni tidak lepas dari wujud tanda yang dihasilkan meskipun secara teoritik terpisah darinya. Berbagai macam wujud budaya dan kultur yang terdapat di Indonesia, menjadikan pemaknaan terhadap karya seni ini 
tidak melulu mengenai konsep akan tetapi menjadi lebih luas, transenden, memiliki nilai kepercayaan atau mitos yang tinggi dan lain sebagainya. Walapun tanda pada karya seni di Indonesia selalu dapat dimaknai dengan kehadiran yang transenden, ini tidak berarti bahwa makna keindahannya terabaikan. Senada dengan Sumardjo (2010: 103) dalam bukunya, makna pada karya seni di Indonesia dapat dibaca melalui konsep besar yang ada di balik simbol, adanya pengalaman seni "keindahannya", dan dapat dibaca secara sistem kepercayaan suku.

Salah satu perwujudan konsep besar yang tergambar pada karya seni di Indonesia dapat dilihat pada Gong Senen yang menjadi simbol dari kebersamaan masyarakat Jepara pada jamannya. Penyematan tanda pada Gong Senen jika dimaknai secara harfiah, merupakan salah satu artefak atau benda pusaka yang perlu dilestarikan. Namun lebih luas lagi, terdapat banyak pemaknaan yang dapat digali guna mengetahui tanda-tanda yang tersemat pada karya seni tersebut.

Tabel 1. Penanda dan Petanda pada Ornamen Gong Senen

[Sumber: Dokumentasi Penulis]

\begin{tabular}{|c|c|}
\hline Penanda (Signifier) & Petanda (Signified) \\
\hline \multicolumn{2}{|l|}{ Elemen Ukir } \\
\hline 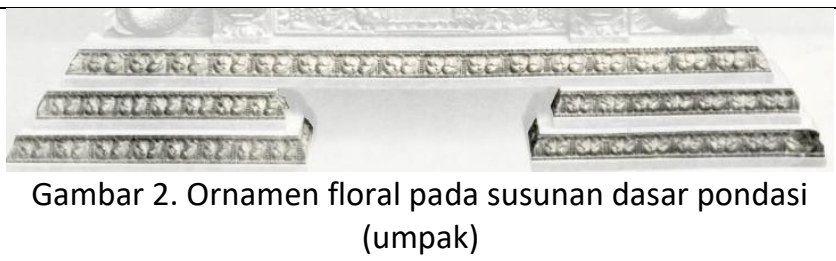 & $\begin{array}{l}\text { mewakili simbol adanya wali songo } \\
\text { (9) yang merupakan awal pondasi } \\
\text { masuk dan tersebarnya ajaran Islam } \\
\text { di tanah Jawa. }\end{array}$ \\
\hline Gambar 3. Motif Jambangan (vas + sluran floral & $\begin{array}{l}5 \text { persilangan di pilar kanan, } 4 \\
\text { persilangan di pilar kiri } \\
\text { mensimbolkan bahwa perbedaan } \\
\text { akan selalu terjadi dalam segi } \\
\text { kehidupan. }\end{array}$ \\
\hline Gambar 4. Motif floral \& buah-buahan & $\begin{array}{l}\text { Falsafah Jawa, "yen wani ojo wedi- } \\
\text { wedi, yen wedi ojo wani-wani". }\end{array}$ \\
\hline
\end{tabular}




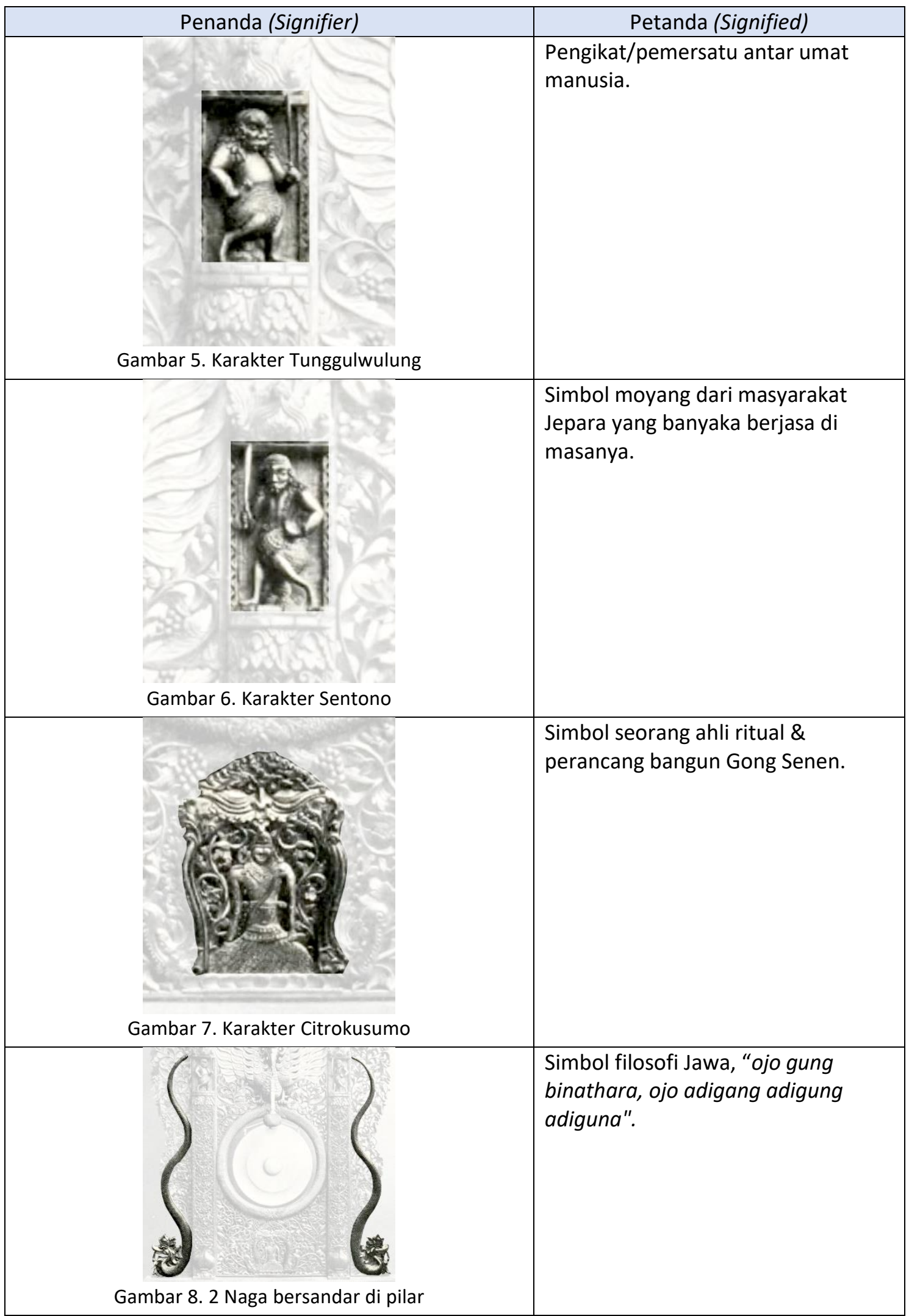




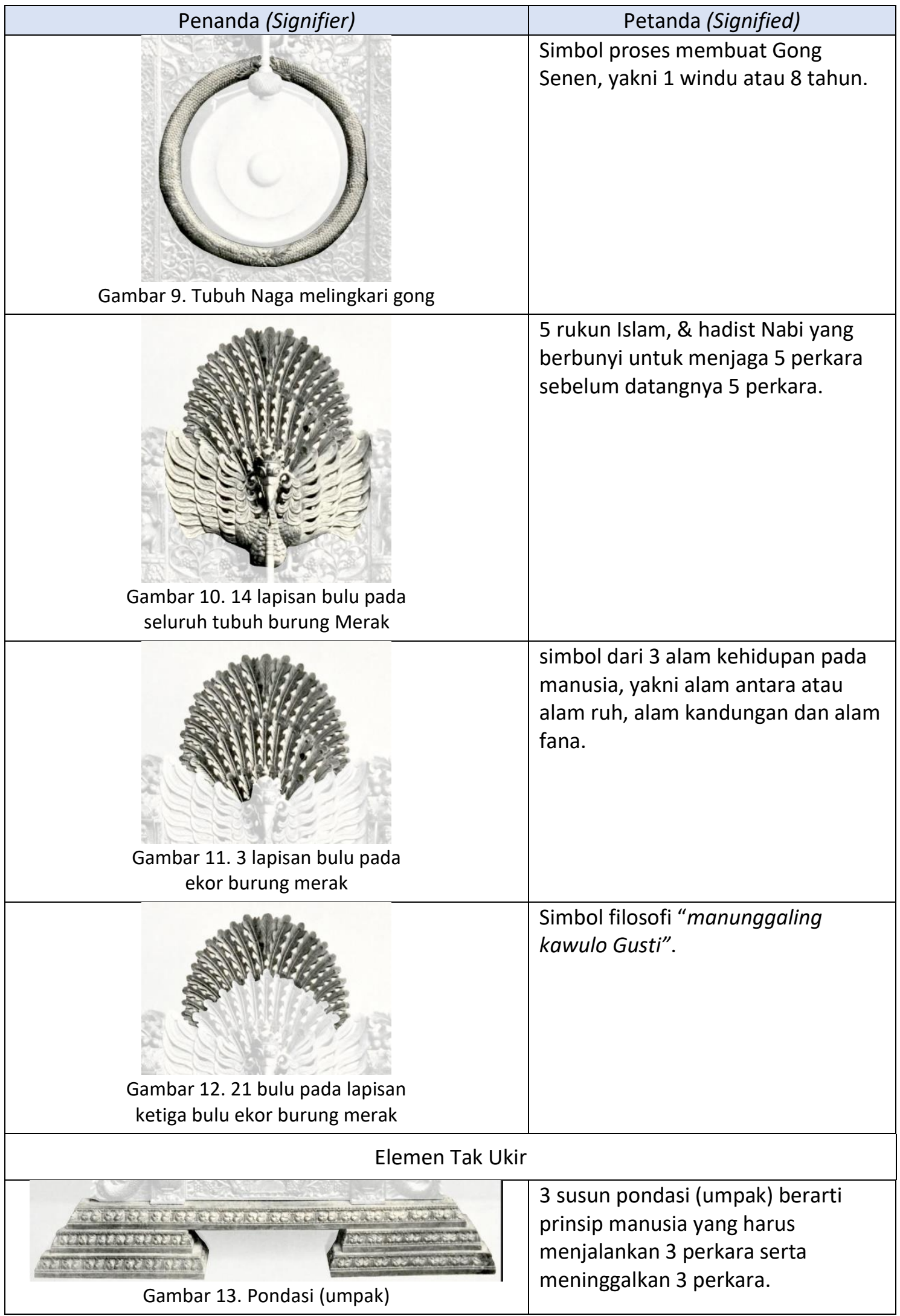




\begin{tabular}{|l|l|}
\hline Penanda (Signifier) & Petanda (Signified) \\
\hline & \\
\hline \\
Gambar 14. Gong
\end{tabular}

\subsection{Representasi Nilai-Nilai Religiusitas Desain Ornamen Gong Senen}

Dalam wacana dunia keseni-rupaan dan budaya benda, pembicaraan estetika yang penting adalah mengupas simbolisme. Hal itu karena manusia bukan saja sebagai makhluk pembuat alat, melainkan juga sebagai makhluk pembuat simbol melalui bahasa visual, (Sachari, 2002: 14). Untuk itu, suatu ornamen selain memiliki fungsi estetik, tidak jarang pula fungsi simbolis (symbolic value) ikut tertanam di dalamnya. Fungsi simbolis yang terkandung dalam ornamen umumnya bisa ditemui pada setiap benda atau artefak yang berhubungan dengan upacara adat istiadat, keagamaan atau kepercayaan, serta pada benda pusaka dan lain sebagainya. Ciri khas nya adalah ornamen pada benda atau artefak tersebut menggunakan motif kala (sengkalan), naga, burung, serta motif makhluk hidup lainnya. Umumnya, para seniman ukir di mana seniman tersebut mengerjakan sendiri ukirannya mulai dari konsep gambar ornamen hingga eksekusi penatahannya maka biasannya tidak meninggalkan pesan-pesan (symbolic value) di dalam makna desain ornamen ukirnya, sebagaimana yang terdapat pada ornamen Gong Senen.

Pada contoh kasus ornamen pada gong Senen, selain memiliki fungsi yang umum seperti sebagai penanda atau simbol media untuk memperkuat hari jadi kota Jepara dan menjadi media pengingat hikayat Jepara, serta sebagai sebuah simbol harapan untuk mempersatukan semua golongan yang ada di Jepara sesuai dengan awal mula tujuan dibuatnya Gong Senen, pada ornamen gong Senen juga terdapat beberapa bagian ornamen yang secara khusus menjadi bahasan tersendiri, dikarenakan masing-masing bagian tersebut memiliki makna fungsi atau nilai simbolik tertentu. Adapun bagianbagian tersebut di antaranya adalah; dimulai dari yang paling dasar, sebagaimana pada Gambar 2., disebutlah umpak atau undak-undakan pada bagian bawah kaki yang merupakan landasan atau pondasi utama bagaimana Gong Senen dapat berdiri dengan kokoh. Dalam pembuatannya umpak memakai hitungan tertentu, dalam tradisi budaya Jawa disebut sebagai ilmu pitung atau ilmu hitung. Fungsi utilities-nya adalah sebagai penguat serta pengikat, maksudnya umpak berfungsi sebagai pondasi yang kokoh dan kuat bagi keseluruhan bagian ukiran pada Gong Senen. Apabila tidak ada umpak atau pondasi yang kokoh tersebut, maka semua bagian pada Gong Senen tidak akan mampu untuk berdiri tegak.

Pondasi (umpak) terdiri dari 3 susun atau lantai, dengan masing-masing lantai terdapat beberapa kotak dengan ukiran ornamen bunga dengan jumlah yang berbeda-beda pada 
setiap lantainya. Adapun makna simbolik dari 3 susun umpak adalah sebagai prinsip manusia yang harus mampu menjalankan 3 perkara serta meninggalkan 3 perkara. Kemudian, pada lantai yang paling dasar, terdapat jumlah kotak berisi ornamen bunga yang berjumlah 36 kotak ornamen, kemudian apabila dijumlahkan masing-masing angkanya maka akan muncul angka 9, angka 9 ini yang kemudian menurut penuturan Nardi, memiliki makna simbol sebagai adanya 9 wali besar yang berada di tanah Jawa (Walisongo). Sembilan wali besar inilah yang dianggap sebagai awal pondasi masuknya dan tersebarnya ajaran Islam di tanah Jawa, khususnya wilayah Jepara.

Selanjutnya, naik ke atas dari umpak, maka berdirilah dua Pilar (gambar 3) yang serupa namun tak sama yang merupakan pilar penyangga dari keseluruhan bagian pada Gong Senen. Kedua pilar ini memiliki makna simbolik sebagai sebuah keseimbangan, keserasian atau konsep berpasang-pasangan dalam kehidupan, seperti adanya pria dan wanita, siang dan malam, baik dan buruk serta adapun yang lain sebagainya.

Disebut 2 pilar yang serupa namun tak sama ini karena ornamen ukirnya pada bagian kiri dan kanan berbeda, perbedaan ornamen ukir pada kedua pilar ini merupakan simbol ukuran kehidupan semua golongan, umat atau orang-orang, di mana kehidupannya tidak ada yang sama, seperti ada yang sederhana, ada yang bermewahan, ada yang bercukupan dan lain sebagainya. Kemudian, dalam masing-masing pilar terdapat ornamen pot bunga di bagian bawah kemudian menjulur 2 batang tanaman yang bersulur-sulur saling bersilangan satu sama lain serta tumbuh beberapa daun dan bunga di setiap batangnya. Ornamen pot bunga pada kedua pilar tersebut memiliki pesan simbolik untuk tidak seenaknya sendiri dalam mengarungi kehidupan, atau harus ada kendali tertentu, karena sebagai makhluk sosial tentu dalam kehidupan tidak untuk hidup sendiri, tetapi juga harus menghidupi yang lain, hidup dan menghidupi, sebagaimana pot bunga dan bunga atau tanaman dalam pot tersebut. Selanjutnya, persilangan antara dua suluran batang tumbuhan di atas pot pada pada masing-masing pilar, jumlahnya juga berbeda. Persilangan tara dua suluran batang tumbuhan di bawah ukiran patung Mbah Tunggulwulung berjumlah 5 persilangan lebih banyak dibanding di bawah Mbah Sentono yang hanya berjumlah 4 persilangan. Nardi (2019) menambahkan bahwa perbedaan persilangan ini menjadikan nilai simbol bahwa yang dinamakan manusia tentu tidak selalu sama, niat bisa jadi sama, namun yang dipikiran bisa jadi berbeda antara manusia satu dengan manusia lain.

Selanjutnya, objek ukir dengan motif buah-buahan sebagaimana pada Gambar 4, memiliki makna simbol yakni dalam berkehidupan, manusia dilarang untuk berputus asa atau putus harapan. Selain itu, Nardi menambahkan bahwa buah-buahan juga memiliki simbol suatu pitutur atau falsafah Jawa yang menyebutkan, "yen wani ojo wedi-wedi, yen wedi ojo wani-wani", yang artinya, "jika berani maka jangan merasa takut, sedangkan jika takut maka jangan pernah berani melakukan sesuatu". Falsafah Jawa ini mengajarkan kepada masyarakat Jepara pada khususnya untuk tidak menjadi manusia yang ragu-ragu dalam bertindak atau dalam mengambil keputusan. 
Ada 3 tokoh atau figur karakter yang diukir dalam Gong Senen, selain merupakan perancang atau pemrakarsa dibuatnya Gong Senen, tokoh-tokoh ini merupakan tokoh berpengaruh di Jepara pada zamannya, maka wajar bila ketokohannya diukir pada beberapa bagian dalam Gong Senen. Ukiran figur pada pilar sebelah kanan adalah Mbah Tunggulwulung (Gambar 5), cirinya adalah tangan kanannya berkacak pinggang, tangan kiri mengacungkan pedang, serta berambut ikal. Sedangkan yang berada di pilar sebelah kiri adalah Mbah Sentono (Gambar 6) dan yang terakhir adalah Mbah Citrokusumo (Gambar 7) yang berada di bawah gong, diukir dengan kondisi duduk bersila seolah-olah tengah bertapa dengan dikelilingi oleh badan kala dan kepala kala berada di atasnya.

Nardi (2019) dalam wawancara menambahkan, adapun nilai simbolik dari ukiran figur Tunggulwulung (Gambar 5) adalah sebagai pengikat semua golongan atau semua ormas (organisasi masyarakat), yang dimaksud golongan adalah antar umat, tidak hanya umat Muslim, tapi juga harus bisa merakyat, dari muslim ke non muslim dan bermacam kepercayaan, khususnya yang ada di Jepara. Selanjutnya, ukiran atau patung figur Sentono (Gambar 6), merupakan simbol nenek moyang dari masyarakat Senenan dan Jepara, beliau telah berjasa bekerja keras serta bekerja sama dengan tokoh-tokoh atau ulama-ulama pada masanya untuk bisa menjadikan adanya kota Jepara yang lebih maju dibanding sebelumnya. Sedangkan ukiran atau patung figur Citrokusumo (Gambar 7) merupakan simbol dari seorang ahli ritual (semedi) dalam budaya Jawa atau Istikhoroh dalam budaya Islam. Citrokusumo adalah tokoh yang mengukir secara keseluruhan dari awal hingga akhir Gong Senen. Selain itu juga merupakan tokoh yang menjadi penentu kapan adanya kisah serta pemberi nama Gong Senen ini, tentunya dengan cara Istikhoroh atau ritual semedi. Maka, dalam ornamen atau relief Gong Senen beliau tidak diukir serupa Sentono dan Tunggulwulung, beliau diukir atau digambarkan dengan kondisi tengah ber-ritual atau semedi untuk menentukan tanggal, hari dan pasaran dalam mengawali pembuatan Gong Senen, dan adapun harinya adalah hari Rabu Legi.

Pada bagian samping atau sayap Gong Senen baik di kanan maupun di kirinya terdapat 2 ukiran patung naga (Gambar 8) berdiri dengan kondisi ekor di atas, badan meliuk bergelombang bersandar pada kedua pilar dan kepalanya di bawah tepat menempel di atas umpak. Naga ini merupakan simbol penguat atau pengikat bagaimana rakyat Jepara khususnya harus mampu bekerja sama, menyatukan ide dan gagasan. Nardi (2019) menambahkan, rakyat Jepara harus mengikuti filosofi Jawa, "ojo gung binathara, ojo adigang adigung adiguna", atau "jangan sok berkuasa, membanggakan kekuatannya, membanggakan kebesarannya serta membanggakan kepandaiannya", termasuk jangan menjadi orang yang rakus dan serakah.

Motif naga yang berada di sisi samping kanan dan kiri gong Senen juga serupa dengan motif naga yang terdapat di cagak untuk gambang kayu gamelan yang berada di Museum Jakarta. Sebagaimana Pepin (1998: 214) nyatakan, pada gamelan orang Jawa alat-alat bunyi-bunyian itu sendiri selalu dibiarkan licin sama sekali, tidak memakai perhiasan (ornamen). Sedangkan barang-barang kayu, tempat menaruh atau menggantungkan alat-alat itu sebaliknya sering dihiasi dengan ukiran-ukiran yang banyak, sering juga diberi berbagai warna. Pada ukiran kayu itu berkali-kali kita dapati 
ragam hias ular (bermahkota), maupun naga. Sebagai contoh, perhiasan cagak (grobogan) untuk gambang kayu, semacam xylophoon atau xylophone (sejenis dengan alat musik gambang) dari kayu, ditaruh di atas bagian pinggir (samping) grobogan tadi, yang menyerupai pembesar bunyi untuk gambang itu. Kepingan kayu itu dipukul dengan semcam pukulan yang gepeng (pipih) yang bernama tabuh, yang longgar dipegang antara ibu jari dan telunjuk. Bunyinya tidak disebabkan dengan tangan, seperti pada alat-alat perunggu. Alat bunyi-bunyian tersebut adalah salah satu dari bagian-bagian gamelan, yang tiap hari Minggu dipakai di Museum di Jakarta.

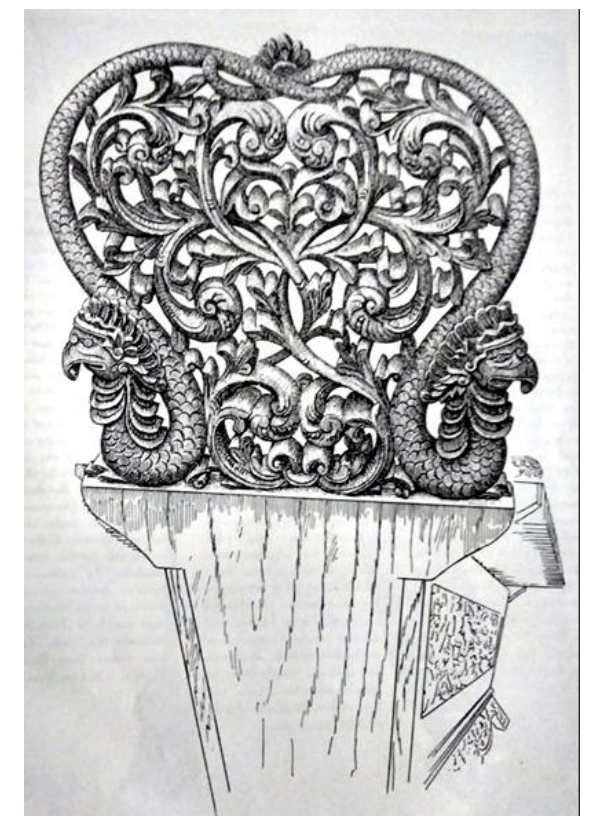

Gambar 14. Gambar Sketsa Ornamen pada Cagak Gamelan Kayu yang Terdapat di Museum Jakarta

[Sumber: Pepin, 1998: 214]

Di antara kedua pilar Gong Senen terdapat tubuh naga (Gambar 9) yang tampak bersisik tanpa kepala dan ekor yang seolah-olah tengah melingkari gong yang sebagai titik pusatnya. Tubuh ular tanpa kepala yang melingkar ini memiliki makna simbol sebagai seluruh unsur ke-duniawi-an, (Nardi, 2019). Sedangkan pada tubuh naga melingkar ini terdapat sisik yang berjumlah 99, Nardi (2019) menambahkan apabila angka 9 dan 9 ini dijumlahkan, dengan mengabaikan nilai satuan atau puluhan nya maka akan muncul angka 18, di mana angka 18 ini melambangkan bahwa jaman dahulu, para pemrakarsa Gong Senen, yakni Citrokusumo, Tunggulwulung dan Sentono dalam membuat Gong Senen ini membutuhkan waktu 1 windu atau 8 tahun.

Perlu diketahui bahwasannya motif ular naga yang terdapat pada ornamen gong Senen merupakan naga khas budaya Jawa. Naga bagi masyarakat Jawa pada khususnya diartikan sebagai makhluk imajiner (mitologis). Anggraini (2014: 52) mengungkapkan bahwa naga hadir dikarenakan imajinasi manusia dalam ruang samadhi (ruang laku tapa) yang berwujud ular besar tetapi tidak ada dalam kehidupan nyata, semua itu berada dalam alam bawah sadar sehingga terlihat fana. Karakteristik naga Jawa adalah tidak berkaki namun memiliki mahkota di kepalanya, berbeda dengan naga khas negeri 
Tiongkok yang biasanya memiliki kaki dan tanpa mengenakan mahkota. Hal ini senada dengan apa yang diungkapkan Anggraini (2014: 52-53), bahwasannya naga digambarkan sebagai sesosok mahluk sakti berbentuk ular raksasa yang tidak memiliki kaki, namun tidak jarang pula diwujudkan mempunyai kaki. Naga dalam masyarakat Jawa disimbolkan dengan memakai badhog atau mahkota di atas kepalanya. Terkadang Naga digambarkan juga memakai perhiasan anting dan kalung emas.

Untuk hitungan-hitungan Jawa keseluruhan seperti dalam naga, burung merak, gong, bunga, alat pemukulnya atau tabuh dan lain-lain, dalam Islam itu menjadi hitungan tasbih yang jumlahnya sama dengan jumlah sisik pada badan naga yang melingkar di tengah, yakni 99 buah. Lalu, jumlah 99 ini dipecah menjadi 2 bagian, 50 pertama adalah merupakan jumlah dari 30 huruf Arab dan 20 aksara Jawa. 20 berikutnya adalah hasil penjabaran atau penjumlahan dari angka-angka 5 dalam jumlah hari pasaran, 7 dalam jumlah hari masehi serta 8 dari jumlah tahun proses pembuatan Gong Senen. Kemudian, sisanya merupakan filosofi dari bagaimana umumnya manusia hidup tidak sendirian, sebagaimana diungkapkan Nardi (2019) dalam wawancara, sebagai makhluk sosial manusia hidup membutuhkan teman, dalam bahasa Islam harus bisa memegang pedoman bahwa manusia sesungguhnya punya kakang kawah adi ari-ari, punya 4 saudara 5 wujud atau sedulur papat limo pancer, dalam istilah Jawa disebutlah sing ngarsa sang sejati sang komodoyo sang komowurug sang komodadi, sedangkan dalam bahasa Agama atau bahasa Arab adalah sufiyah (unsur air), aluamah (unsur angin), muthmainah (unsur tanah) dan amarah (unsur api).

Sedangkan Gong (gambar 14) di tengahnya merupakan objek tak ukir dari keseluruhan komponen pada Gong Senen. Gong berbahankan perunggu yang menjadi titik pusat dari mahakarya ukiran Jepara ini memiliki makna simbolik sebagai perumpamaan Sang Maha Segalanya, yakni Alloh Subhanahu wa Ta'ala, merupakan titik pusat di mana seluruh makhluk dan semesta bersujud kepada-Nya. Nardi (2019) dalam wawancars menambahkan, disebut "Gong" karena apabila titik pusat lengkungannya dipukul oleh alat pemukulnya (tabuh) maka akan bersuara seperti "guoong". Bunyi ini kemudian oleh perancang gong senen, Citrokusumo, dikaitkan dengan bunyi terakhir pada salah satu sifat Alloh, di mana orang Jawa menyebutnya dengan, "Gusti ingkang Moho Agùng" atau Tuhan yang Maha Agung. Di mana bunyi ucapan huruf vokal (ù) pada kata Agùng hampir menyerupai bunyi ucapan huruf vokal (o).

Objek ukir terakhir adalah pada bagian burung merak (Gambar 10) yang mengepakkan sayap dan ekornya. Ukiran burung merak ini terdapat atau terdiri dari 14 lapisan bulu merak pada seluruh bagian pada tubuh merak, seperti pada badan, sayap, ekor serta bagian-bagian lainnya. Selanjutnya, Nardi (2019) mengungkapkan bilamana angkaangka pada jumlah lapisan bulu merak tersebut dijumlahkan maka akan muncul angka 5 yang memiliki nilai simbol dari 5 rukun Islam serta adanya hadits Nabi Muhammad SAW untuk menjaga 5 perkara sebelum datangnya 5 perkara, yakni; jogo enommu sakdurunge teko tuomu, jogo sehatmu sakdurunge teko loromu, jogo sugihmu sakdurunge teko mlaratmu, jogo sempatmu sakdurunge teko sempitmu serta jogo uripmu sedurunge teko matimu. Kemudian pada bagian ekor merak (Gambar 11), di 
mana pada bagian ekor merak ini terdapat 3 lapisan bulu dan setiap lapisan bulunya terdapat jumlah bulu yang berbeda pada setiap lapisannya. 3 lapisan bulu pada ekor merak ini merupakan simbol dari 3 alam kehidupan pada manusia, yakni alam antara atau alam ruh, alam kandungan, dan yang terakhir adalah alam fana.

Selanjutnya, pada lapisan terakhir pada ekor merak ini (Gambar 12), di mana merupakan simbol dari alam fana atau alam dunia terdapat 21 bulu yang memiliki pesan-pesan dalam menjalani kehidupan di alam yang fana ini. Nardi dalam wawancaranya menambahkan, angka 21 di mana cara membacanya adalah dari 2 hal yang menjadi 1 atau menyatu, merupakan simbol dari filosofi Jawa "manunggaling kawulo Gusti". Nurbaya sebagaimana dikutip Nurlailiyah (2013: 13) dalam penelitiannya mengungkapkan bahwa konsep manunggaling kawulo Gusti dikenal sebagai ajaran tasawuf Syekh Siti Jenar yang merupakan salah satu wali pada masa Walisongo atau pada masa peralihan kekuasaan di Jawa, dari Majapahit ke pemerintahan Islam Raden Fatah di Demak Bintoro. Konsep yang dalam bahasa Islam-nya disebut dengan wahdatul wujud ini secara garis besar adalah bahwa Sang Pencipta merupakan tempat kembali semua makhluk, dengan kembali kepada Tuhannya, maka manusia telah bersatu dengan Tuhannya. Dalam ajarannya pula, manunggaling kawula Gusti bermakna bahwa di dalam diri manusia terdapat roh yang berasal dari roh Tuhan sebagaimana intisari ayat Al-Quran yang menerangkan tentang penciptaan manusia:

"Ketika Tuhanmu berfirman kepada malaikat: "Sesungguhnya Aku akan menciptakan manusia dari tanah. Maka apabila telah Kusempurnakan kejadiannya dan Kutiupkan kepadanya roh-Ku, maka hendaklah kamu tersungkur dengan bersujud kepadanya. "Q.S. Shaad: 71-72"

Selain itu, dalam badan merak, yang di mana seluruh ukiran bulu-bulu merak berpusat pada ukiran ini mengandung makna simbolik tersendiri sebagai sebuah harapan dari para kreator Gong Senen agar kelak rakyat Jepara mampu terus untuk bersatu dan "merak"-yat (merakyat). Kemudian, pada mulut merak terdapat pengait untuk mengaitkan atau menggantung alat pemukul gongnya, atau yang disebut dengan tabuh. Dalam tabuh ini terdapat 5 ukiran berbentuk lingkaran di bagian atas, serta 7 lingkaran di bagian bawahnya. 5 lingkaran menunjukkan 5 hari pasaran, yakni kliwon, legi, pahing, pon dan wage, sedangkan 7 lingkaran menunjukkan hari masehi mulai jumat hingga kamis. Fungsi tabuh adalah sebagai media untuk membunyikan gong dengan cara dipukulkan ke sebuah bagian satu lengkungan yang menonjol dalam gong. Di mana sebuah lengkungan yang menonjol pada gong ini menunjukkan makna simbol bahwa dalam mempersatukan umat antar golongan itu tujuannya hanya satu, yakni kembali ke Yang Maha Satu atau Maha Esa.

Baik motif floral pada ornamen ukir Gong Senen maupun ornamen yang lainnya, Sutrisno (2012: 26) dalam buku Pelangi di Tanah Kartini, menyebutkan bahwa makna simbolik yang terkandung dari ornamen yang mengandung unsur flora dan fauna adalah adanya filosofi yang mengakar dalam hidup kerakyatan, di mana filosofi tersebut memiliki tujuan sebagai simbol kesuburan dan kemakmuran. Kesuburan dan kemakmuran adalah filosofi yang sering ditemui dalam ornamen-ornamen di sekitaran candi-candi di tanah Jawa, seperti ornamen pada Candi Prambanan, Borobudur dan 
candi lainnya. Filosofi yang 'adiluhung' (Jawa klasik) seperti ini seharusnya melekat pada setiap pengrajin ukir relief guna menghargai hasil ciptaan orang lain atau penghargaan bagi penciptanya. Di sisi lain, keberadaan motif floral dalam suatu ornamen terkadang memiliki fungsi sebagai pengisi bidang-bidang kosong dalam ornamen serta berfungsi sebagai frame (bingkai) suatu ornamen. Ukiran floral tumbuhan yang bersulur-sulur ini merupakan salah satu ciri khas ukiran motif Jepara. Ukiran dengan motif demikian ini seringkali ditemui pada ukiran dalam gebyok, hiasan dinding, furnitur rumahan dan lain sebagainya yang secara khusus dibuat oleh para seniman ukir Jepara.

Motif-motif makhluk hidup pada ornamen gong Senen seperti motif fauna dan figur manusia (karakter) nya diukir dengan cara penggambaran yang naturalis tentu bertentangan dengan ajaran Islam. Hal ini justru begitu kontradiktif apabila dilihat kondisi wilayah di Jepara yang pada masa tersebut merupakan daerah penguasaan Kerajan Islam Mataram. Namun, meskipun demikan, apabila dianalisa lebih lanjut, akulturasi prinsip-prinsip ajaran Islam justru masuk dan melekat kedalam makna simbolis/filosofis pada berbagai motif ornamen tersebut. Hal yang serupa tidak jauh berbeda dengan bagaimana Sunan Kalijaga mendakwahkan ajaran Islam namun menggunakan media seni wayang kulit yang sejatinya merupakan hasil kebudayaan Hindu-Budha-Jawa. Contoh kasus demikian ini tidak terlepas dari prinsip manusia Jawa atau manusia Indonesia sebagaimana diungkapkan oleh Tabrani (1999: 19) bahwa semua yang datang dari luar pasti diolah hingga tinggi muatan lokalnya, bahkan juga muatan kebangsaannya.

\section{KESIMPULAN}

Di balik kemegahan desain oranmen ukir karya masterpiece Citrokusumo yang terlukis dalam setiap lekuk ornamennya, tidak hanya merepresentasikan nilai-nilai religiusitas semata, namun banyak nilai-nilai filosofi kehidupan Adiluhung Jawa yang juga terrepresentasi di dalamnya, yang hendak disampaikan Adipati Jepara tersebut untuk seluruh warganya. Nilai-nilai tersebut secara umum meliputi hubungan manusia dengan Tuhannya, sesamanya serta lingkungannya. Sebagai contoh, ukiran burung merak pada Gong Senen bagian atas memiliki makna dan pesan kepada warga Jepara khususnya untuk menjaga 5 perkara sebelum datangnya 5 perkara, yakni menjaga masa muda sebelum tua, sehat sebelum sakit, kaya sebelum miskin, sempat sebelum sempit, serta hidup sebelum mati.

Adapun beberapa saran yang bisa diberikan peneliti dalam penelitian ini di antaranya adalah 1) Saran kepada peneliti berikutnya untuk mampu mengemas nilai-nilai religiusitas yang penuh filosofi kehidupan dari ornamen ukir Gong Senen ini menjadi sebuah media informasi yang menarik dan mudah dipahami bagi para khalayak luas, khususnya warga Jepara. 2) Saran kepada warga Jepara khususnya untuk mengimplementasikan nilai-nilai falsafah kehidupan yang terkandung dalam ornamen ukir Gong Senen ini sebagaimana tujuan Citrokusumo dulu dalam merancangnya. Dan, 3) Saran kepada pemerintah Jepara untuk mengambil peran dalam melestarikan kebudayaan yang berasal dari wilayah Jepara, sehingga bisa diwariskan kepada generasi yang akan datang. 


\section{DAFTAR PUSTAKA}

Anggraini, R. A. (2014). Simbol-simbol Budaya dalam Desain Keris Naga Kamardikan Karya Mpu Pathor Rahman. STIKOM Surabaya, Surabaya.

Berger, A. A. (2000). Tanda-tanda dalam Kebudayaan Kontemporer. Yogyakarta: PT. Tiara Wacana.

Copplestone, T. (1983). Art in Society: A Guide to the Visual Arts: Englewood Cliffs. New Jersey: Prentice Hall, Inc.

Eco, U. (1979). A Theory of Semiotics. Blommington: Indiana University Press.

Kartini. (1903, January 3). Van Een Vergeten Uithoekje. dalam Eigen Haard.

Mulyadi, M. (2011). Penelitian Kuantitatif dan Kualitatif serta Pemikiran Dasar Menggabungkannya. Jurnal Studi Komunikasi Dan Media, 15(1), 127-138.

Nurlailiyah, A. (2013). Filsafat Pendidikan Jawa dalam Pemikiran Syekh Siti Jenar (Studi Analisis Syerat Siti Djenar Versi Tan Khoen Swie). UIN Sunan Kalijaga Yogyakarta, Yogyakarta.

Pepin, V. R. (1998). Indonesian Ornamental Design. Singapore: Pepin Press Book.

Piliang, Y. A. (2004). Semiotika Teks: Sebuah Pendekatan Analisis Teks. Mediator, 5(2), 189-198.

Sachari, A. (2002). Estetika Makna, Simbol dan Daya. Bandung: ITB.

Sumardjo, J. (2010). Estetika Paradoks. Bandung: Sunan Ambu Press.

Sutrisno (Ed.). (2012). Perjalanan Hidup Pengukir Relief: Kampung, dalam Pelangi di Tanah Kartini: Kisah aktor mebel Jepara bertahan dan melangkah ke depan. Bogor: Cifor.

Tabrani, P. (1999). Belajar dari Sejarah dan Lingkungan - Sebuah Renungan Mengenai Wawasan Kebangsaan dan Dampak Globalisasi. Bandung: ITB. 